\title{
Potential of the entomopathogenic nematode, Heterorhabditis marelatus, isolate in controlling the peach fruit fly, Bactrocera zonata (Saunders) (Diptera: Tiphritidae)
}

\author{
M. M. E. Saleh ${ }^{*}$ (D, Hala M. S. Metwally and Y. A. Mahmoud
}

\begin{abstract}
The peach fruit fly, Bactrocera zonata (Saunders) (Diptera: Tiphritidae), is an economic insect pest attacking the fruits of mangoes, apricots, guava, citrus, and peaches. This pest is difficult to be controlled by the traditional chemicals due to the behavior of its larvae that hide inside the fruits or its pupae that pupate in the soil. The present study documented the molecular identification and the first record of the entomopathogenic nematode, Heterorhabditis marelatus D1 from Egypt. Environmental characterization showed that the new isolate was superior than the commercialized species, Heterorhabditis bacteriophora, in heat tolerance (higher more than five times), desiccation tolerance (higher than four times), and hypoxic tolerance (higher than about two times). Comparative virulence of the reference nematode to the larvae of the great wax moth, Galleria mellonella L., was carried out. When applied to the soil, the new isolate showed high potency in controlling B. zonata adults emerged from their pupae as it killed over $77 \%$ of the adults within $48 \mathrm{~h}$ after emergence.
\end{abstract}

Keywords: Bactrocera zonata, Heterorhabditis marelatus D1, Environmental tolerance, Mortality

\section{Background}

Entomopathogenic nematodes (EPNs) of genera Steinernema and Heterorhabditis associated with specific bacteria (of the genera Xenorhabdus and Photorhabdus) are efficient bio-control agents for many insect pests that spend a part of their life cycle in the soil or cryptic habitats (Koppenhofer 2000) and also the foliar pests (Laznik et al. 2010). The free living infective juveniles (IJs) attack insects through natural openings in Steinernema spp. and the weak spots of the insect cuticle in Heterorhabditis spp. and release the bacteria in the host blood, where they cause blood septicemia and death of the insect within 24-48 h. EPNs have a high reproductive potential and a broad host range and are easily applied with conventional spraying equipment. These beneficial nematodes leave no chemical or polluting residues so that they have been exempted from registration for commercialization in Europe and the USA (Gaugler

\footnotetext{
* Correspondence: mmesaleh@hotmail.com

Pests and Plant Protection Department, National Research Centre, Elbehooth Street, Dokki, Cairo, Egypt
}

\section{Springer Open}

(c) The Author(s). 2018 Open Access This article is distributed under the terms of the Creative Commons Attribution 4.0 International License (http://creativecommons.org/licenses/by/4.0/), which permits unrestricted use, distribution, and reproduction in any medium, provided you give appropriate credit to the original author(s) and the source, provide a link to the Creative Commons license, and indicate if changes were made. several decades; however, improvement is needed to realize their full potential for broader application in agriculture. Improvements could be gained through selective breeding and the isolation of additional species and populations (Anbesse et al. 2013). Molecular identification and genotyping of EPNs are essential for their proper classification, biodiversity studies, and their potential use in biological control programs. The success of EPNs in insect control depends on the environmental conditions under which the nematodes are applied (Grewal et al. 2006). Environmental factors, such as soil temperature and moisture content, could prevent the EPNs from realizing their full potential as biological control agents (Kaya and Koppenhofer 1996; Smits 1996; Perry et al. 2012). Therefore, collection of EPNs from diverse native geographic locations is important. Screening for EPN species or isolates with extreme environmental tolerance may contribute to reducing costs and increasing efficacy.

The peach fruit fly, Bactrocera zonata (Saunders) (Diptera: Tephritidae), is a destructive fruit pest of 
peach, guava, mango, apricot, and citrus in tropical countries (Kapoor 1993; Shehata et al. 2006). The difficulty of controlling this pest comes from its larvae hiding inside the fruits and its pupae pupate in the soil. Mahmoud et al. (2016) stated that EPNs can infect different stages of $B$. zonata. Nematodes can reach larvae inside falling guava fruits through the interface region with the soil surface. They infect the newly formed pupae in soil as well as the pest adults during their emergence from pupae.

The present study aimed to evaluate the potential of a new entomopathogenic nematode isolate against stages of the peach fruit fly, B. zonata.

\section{Materials and methods \\ Molecular identification DNA isolation}

DNA isolation was achieved using Quick Extract Kit (Epicenter, USA) according to the procedure provided by the manufacturer. Nematodes were centrifuged at $1700 \times g(5000 \mathrm{rpm})$ in a micro-centrifuge for $3 \mathrm{~min}$. The pellet was washed once with $0.5 \mathrm{ml}$ of sterile water and then was centrifuged at $1700 \times g(5000 \mathrm{rpm})$ for $3 \mathrm{~min}$. The supernatant was discarded, and $100 \mu \mathrm{l}$ of Quick Extract DNA Extraction Solution and $1 \mu \mathrm{l}$ of Ready-Lyse Lysozyme Solution was added and incubated for $15 \mathrm{~min}$. The solution was heated at $80{ }^{\circ} \mathrm{C}$ for $2 \mathrm{~min}$, then diluted in TE Buffer $(10 \mathrm{mM}$ Tris- $\mathrm{HCl} \mathrm{pH}=7.5,1 \mathrm{mM}$ EDTA). The DNA samples were stored at $-20{ }^{\circ} \mathrm{C}$. DNA concentration and their purity were determined using an UV spectrophotometer at optical density of 260 and $280 \mathrm{~nm}$.

\section{Polymerase chain reactions (PCR)}

Reactions were performed using specific primer for gene under study. The 28S rRNA gene was amplified with primers fD1 (forward, AGCGGAGGAAAAGAAACTA) and $\mathrm{rP2}$ (reverse, TACTAGAAGGTTCGATTAGTC), producing an amplicon of approximately $1500 \mathrm{bp}$. The PCR was made in $50 \mu \mathrm{l}$ of a reaction mixture consisting of $0.25 \mu \mathrm{M}$ each primer, $0.2 \mathrm{mM}$ deoxynucleoside triphosphates, $1.5 \mathrm{mM} \mathrm{MgCl} 2,5 \mu \mathrm{l}$ of $\times 10 \mathrm{Taq}$ buffer, 1.5 units of Taq, and $5 \mu \mathrm{l}$ of DNA. PCR was performed in a GeneAmp PCR system 9700 (Applied Biosystems Inc.) with a pre-incubation step of $94{ }^{\circ} \mathrm{C}$ for $5 \mathrm{~min}$ and 40 cycles at $94{ }^{\circ} \mathrm{C}$ for $1 \mathrm{~min}, 60{ }^{\circ} \mathrm{C}$ for $1 \mathrm{~min}$, and $72{ }^{\circ} \mathrm{C}$ for $1.5 \mathrm{~min}$, followed by a final extension step of $72{ }^{\circ} \mathrm{C}$ for $10 \mathrm{~min}$ (Marin et al. 2011). A size of $10 \mu \mathrm{l}$ of the amplification product was electrophoresed on a $2 \%$ agarose gel and stained with ethidium bromide. The size of amplified product was determined by comparing to a 100 bp molecular weight ladder.

\section{Sequence analysis}

The PCR product of 28S rRNA gene was purified and sequenced by Macrogen Incorporation (Seoul, Korea). Then, sequencing data were compared against the GenBank database to identify the homology between them using NCBI/BLAST/blastn suite.

\section{Environmental tolerance}

The following tests were applied on the local isolate $H$. marelatus D1 in comparison to H. bacteriophora.

\section{Heat tolerance}

A concentration of $2000 \mathrm{IJs} / \mathrm{ml}$ was prepared in $100-\mathrm{cm}^{3}$ flask for each tested nematode species. A volume of $1 \mathrm{ml}$ was transferred in a $15-\mathrm{cm}^{3}$ test tube sealed with paraf$\mathrm{ilm}$ and replicated nine times. The tubes were placed in a shaker at $70 \mathrm{rpm}$ on $40{ }^{\circ} \mathrm{C}$ for 2,4 , or $6 \mathrm{~h}$. At each interval, three tubes were taken out and a volume of 9-ml water was added to each of them. The tubes were then kept at $25{ }^{\circ} \mathrm{C}$ for $24 \mathrm{~h}$. Nematode mortality was assessed under a stereomicroscope at three samples from each tube of $100 \mu \mathrm{l}$ per sample. Results were recorded and statistically analyzed by ANOVA, and means were separated by LSD.

\section{Desiccation tolerance}

Desiccation tolerance was evaluated by dehydrating the IJs in a glycerol as described by Glazer and Salame (2000). A concentration of $2000 \mathrm{IJs} / \mathrm{ml}$ was prepared in a $100-\mathrm{cm}^{3}$ flask for each nematode species. Glycerol was added to a volume of $0.5 \mathrm{ml}$ of nematode suspension to create 2, 5, and $10 \% v / v$ glycerol/nematode suspension in $20-\mathrm{cm}^{3}$ test tubes. Each glycerol concentration was replicated nine times for each nematode species. The tubes were placed on a shaker $70 \mathrm{rpm}$ in $25{ }^{\circ} \mathrm{C}$ and $75-85 \% \mathrm{RH}$ for 2,4 , and $6 \mathrm{~h}$. At every interval, a sample of three tubes were taken out and a volume of 5-ml water was added to each tube. Tubes without glycerol were prepared and served as control. The tubes were then kept at $25{ }^{\circ} \mathrm{C}$ for $24 \mathrm{~h}$. Nematode mortality rate was assessed from three subsamples from each tube under a stereo-zoom microscope (100 $\mu$ l per sample). Results were recorded and statistically analyzed by ANOVA, and means were separated by LSD.

\section{Hypoxia tolerance}

Hypoxia tolerance is the ability of infective juvenile nematodes to survive lack of oxygen. Hypoxia of the new isolate and the reference nematode $H$. bacteriophora were compared. A concentration of 10,000 nematodes/ $\mathrm{ml}$ was prepared for each nematode. A volume of $1.5 \mathrm{ml}$ of nematode suspension was placed in each one of a 2-ml Ependorf tube with a tightly closed led. These experiments were repeated nine times for each 
nematode. All tubes were kept at $25{ }^{\circ} \mathrm{C}$ in dark for 24 , 48 , and $72 \mathrm{~h}$. At each interval, three tubes were taken and each of them was decanted into a Petri dish filled with $15 \mathrm{ml}$ water. Dishes were kept at $25{ }^{\circ} \mathrm{C}$ for $24 \mathrm{~h}$. Nematode mortality was assessed under a stereo-zoom microscope at three samples from each dish at $100 \mu \mathrm{l}$ per sample. Results were recorded and statistically analyzed by ANOVA, and means were separated by LSD.

\section{Virulence against $G$. mellonella larvae}

The greater wax moth G. mellonella is maintained continuously in the laboratory of Pests and Plant Protection, National Research Center, Egypt. The new isolate and the reference nematode, $H$. bacteriophora, were bio-assayed for their virulence against larvae of G. mellonella, using multi-cell plates. Each cell of $1-\mathrm{cm}$ diameter and $1 \mathrm{~cm}$ high is furnished with a disc of filter paper. Last instar larvae of G. mellonella were individually placed in the cells. Nematode concentrations of 0, 5, 10, 20, 50, and 100 IJs/ $100 \mu \mathrm{l}$ of water were applied on the larvae. Each concentration was applied on 24 larvae distributed in four replicates (each of 6 larvae). Plates were covered and kept at $25{ }^{\circ} \mathrm{C}$. Control plots received water only. Larval mortality was recorded daily for 3 days and Probit analysis was applied. Values of half lethal concentration $\left(\mathrm{LC}_{50}\right)$ at 3-day exposure and values of half lethal time $\left(\mathrm{LT}_{50}\right)$ at $20 \mathrm{IJs} /$ $100 \mu \mathrm{l}$ concentration of both nematodes were compared.

\section{Effect on the peach fruit fly}

The peach fruit fly, B. zonata, is maintained continuously in the laboratory of Pests and Plant Protection, National Research Center, Egypt. Adults of the peach fruit fly emerging from their pupae in the soil were the target of this assay. Plastic containers of $500-\mathrm{cm}^{3}$ and $100-\mathrm{cm}^{2}$ surface area filled with heat-sterilized sand were used. Soil in each container was artificially infested with 25 pupae ( 1 week old) of B. zonata and wetted with $15 \% w / w$ water. The new isolate and the reference nematode $H$. bacteriophora were applied on the soil at two rates (5 and 15 nematodes $/ \mathrm{cm}^{2}$ of soil surface) and kept at $25 \pm 2{ }^{\circ} \mathrm{C}$. Four containers were specified for each treatment. Control plots received only water. After 1 week, insect cadavers were dissected for nematode infection under a stereomicroscope and only those cadavers containing developing nematodes were recorded as nematodeinfected ones. Data were compared using ANOVA.

\section{Results and discussion}

\section{Molecular identification}

The sequence alignment of $28 \mathrm{~S}$ ribosomal RNA gene of the new isolate was compared to those published in GenBank under Accession number: DQ 145665.1, and showed $100 \%$ identities as Heterorhabditis marelatus (Table 1). Then, this new isolate was called Heterorhabditis marelatus D1.
Table 1 Heterorhabditis marelatus 28S ribosomal RNA gene, partial sequence. Sequence ID: gb|DQ145665.1|Length: 913Number of Matches: 1

\begin{tabular}{lllll}
\hline Score & Expect & Identities & Gaps & Strand \\
\hline 1604 bits(868) & 0.0 & $868 / 868(100 \%)$ & $0 / 868(0 \%)$ & Plus/Minus \\
\hline
\end{tabular}

The present study has documented the first record of H. marelatus D1 from Egypt. It was isolated and molecularly identified from a sandy soil of a fruit orchard on Alexandria desert road, Egypt. In 1996, H. taysearae was recorded as a new species from the same region (Shamseldean et al. 1996). Grewal et al. (2006) stated that isolation and molecular identification for additional species and populations of EPNs are needed for proper classification, for biodiversity studies, and for improving the role of EPNs in biological control. Information on the environmental tolerance of EPNs is useful in the selection of strains that are needed for field application (Shulong et al. 2013).

\section{Environmental tolerance \\ Heat tolerance}

Infective juveniles of the newly isolated nematode $H$. marelatus D1 expressed higher heat tolerance than the reference nematode $H$. bacteriophora (Fig. 1). Exposing the IJs to $40{ }^{\circ} \mathrm{C}$ for 2,4 , and $6 \mathrm{~h}$ resulted in $1.39,2.36$, and $10.69 \%$ mortality in $H$. marelatus D1. However, the respective mortality percentages in $H$. bacteriophora were $5.13,14.7$, and $58.83 \%$. At 2 -h exposure to $40{ }^{\circ} \mathrm{C}$, the difference in heat tolerance between the two nematodes was insignificant. Starting from 4-h exposure, the new native isolate showed highly significant heat tolerance than the reference nematode. At 6-h exposure, $H$. marelatus D1 showed five times higher heat tolerance than H. bacteriophora.

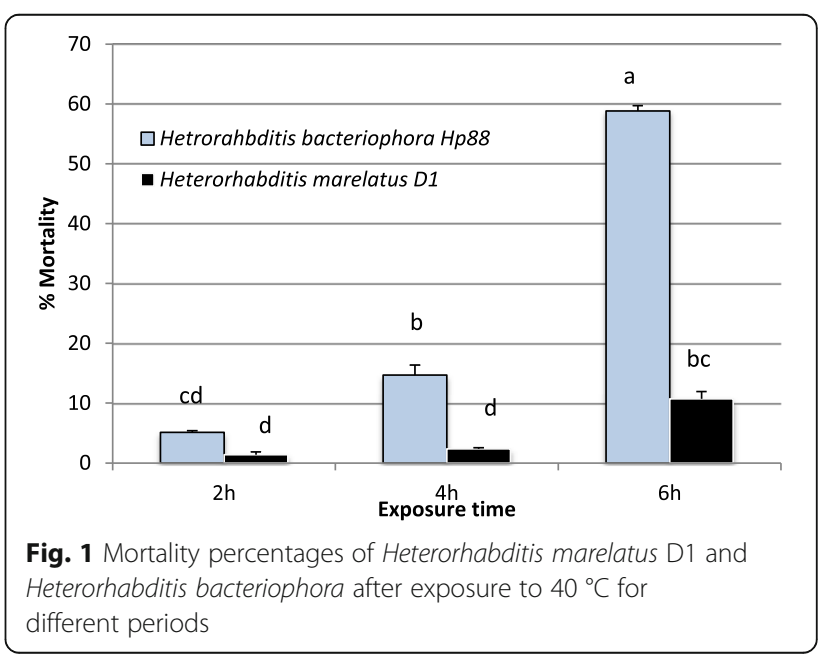




\section{Desiccation tolerance}

Desiccation tolerance of the newly isolated nematode $H$. marelatus D1 and the reference nematode $H$. bacteriophora was assessed by soaking the nematodes in the dehydrating glycerol solutions 2,5 , and $10 \%$ for 2 , 4 , and $6 \mathrm{~h}$. The results of this test are illustrated in Fig. 2. Soaking the nematodes in $2 \%$ glycerol resulted in 5 and $2.91 \%$ mortality in $H$. bacteriophora and $H$. marelatus D1, respectively. This difference was found insignificant at $P<0.5 \%$ ANOVA. $H$. marelatus D1 expressed highly significant desiccation tolerance over $H$. bacteriophora when either the soaking period or the glycerol concentration increased. At $2 \%$ glycerol and 4-h exposure period, the mortality percentages in $H$. bacteriophora and $H$. marelatus D1 were 23 and $2.91 \%$, respectively. At $2 \%$ glycerol and 6-h exposure, the respective mortality percentages became 48.12 and $9.44 \%$. At $10 \%$ glycerol and 6-h exposure, the mortality rate in the reference nematode $H$. bacteriophora reached $92.84 \%$, while it was only $18.76 \%$ in the newly isolated nematode $H$. marelatus D1. Obtained results mean that desiccation tolerance of new isolate was four times higher than the reference nematode.

\section{Hypoxia tolerance}

When $H$. marelatus $\mathrm{D} 1$ and $H$. bacteriophora were exposed to lack of oxygen for 24,48 , and $72 \mathrm{~h}$, they showed significantly different hypoxic tolerance (Fig. 3). At $24 \mathrm{~h}$ of hypoxic conditions, mortality in $H$. marelatus D1 was $3.23 \%$, while it was $14.44 \%$ in H. bacteriophora. Greater difference in hypoxic tolerance between the two nematodes was clearly observed at 48- or 72-h exposure periods. At 72-h exposure, mortality percentages were 8.25 and $23.34 \%$ for $H$. marelatus $\mathrm{D} 1$ and $H$. bacteriophora, respectively. Hypoxic tolerance of $H$. marelatus D1 was twice as high as H. bacteriophora.

In the present study, $H$. marelatus D1 was tested for environmental tolerance under which it will be probably

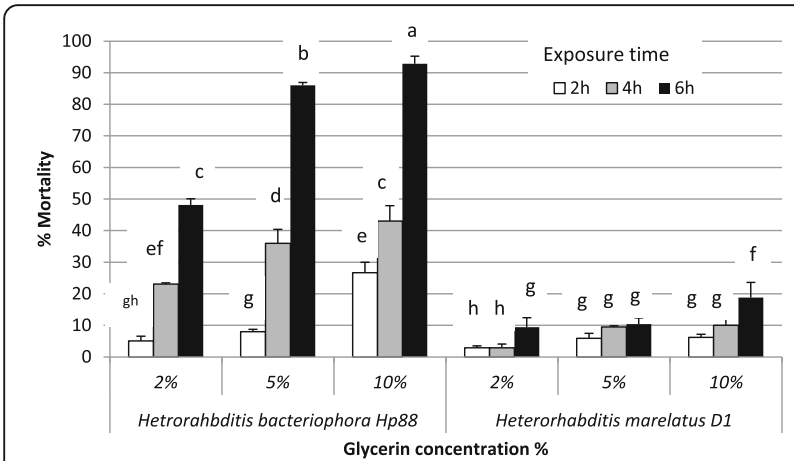

Fig. 2 Mortality in infective juveniles of Heterorhabditis bacteriophora and Heterorhabditis marelatus D1 after exposure to 2, 5, and 10\% glycerol for 2, 4, and $6 \mathrm{~h}$

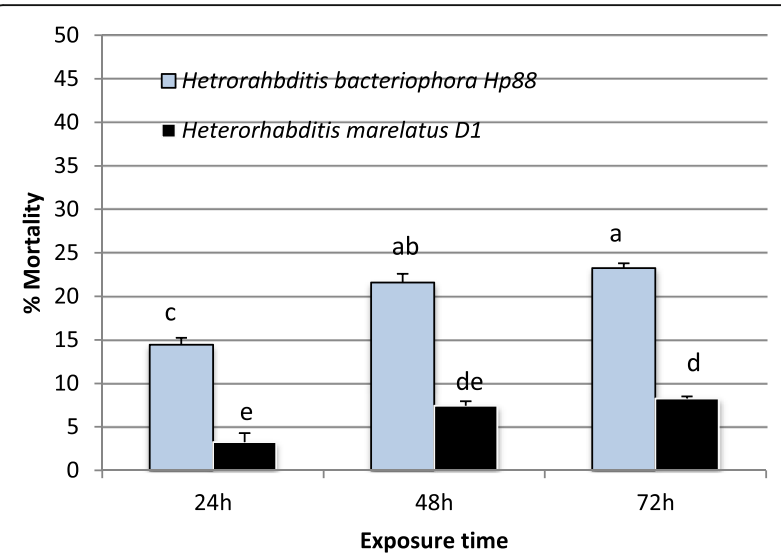

Fig. 3 Comparison of mortality of infective juveniles of Heterorhabditis marelatus D1 and H. bacteriophora after exposure to hypoxic conditions for different periods

applied, i.e., heat, desiccation, and hypoxia. The new isolate was superior than the most commercialized species $H$. bacteriophora in heat tolerance (as high as more than 5 times) desiccation (over 4 times higher survival) and hypoxic tolerance (as high as about two times). In a previous heat tolerance assay, the native nematode $H$. bacteriophora S1 (Shamseldean et al. 1996) showed 80\% infectivity to G. mellonella larvae at $35{ }^{\circ} \mathrm{C}$ compared to only $20 \%$ infectivity given by the reference nematode $H$. bacteriophora (El-Saadawy and Saleh 1999). Shamseldean (1994) reported that Egyptian heterorhabditids survived at $35{ }^{\circ} \mathrm{C}$ for $48 \mathrm{~h}$. The use of EPNs is constrained by high temperature in tropical and semitropical regions (Molyneux 1986). Kaya (1990) stated that the temperature range of infection of a given nematode depends on its native home. According to Gaugler $(1988,1997)$ the native EPNs provides superior control when compared to non-native ones.

\section{Virulence to the larvae of G. mellonella}

The isolate, $H$. marelatus $\mathrm{D} 1$, and the reference nematode, $H$. bacteriophora, showed comparable virulence ability against larvae of G. mellonella (Fig. 4). At the lowest concentration ( $5 \mathrm{IJs} / 100 \mu \mathrm{l} / \mathrm{larva})$ and 24 -h exposure period, the new isolate and the reference nematode caused 8.33 and $10 \%$ larval mortality, respectively. At the highest concentration (100 IJs/100 $\mu \mathrm{l} /$ larva) and 72-h exposure period, the larval mortality was 87.5 and $95.83 \%$ for $H$. marelatus $\mathrm{D} 1$ and $H$. bacteriophora, respectively.

Obtained results showed that although $H$. marelatus D1 had stronger environmental tolerance traits, it was comparable to $H$. bacteriophora in terms of virulence to either G. mellonella or the fruit fly B. zonata. Several studies have indicated that traits of EPNs may differ among strains/species, including their longevity, virulence, and environmental tolerance (Shapiro-Ilan et al. 2003; 


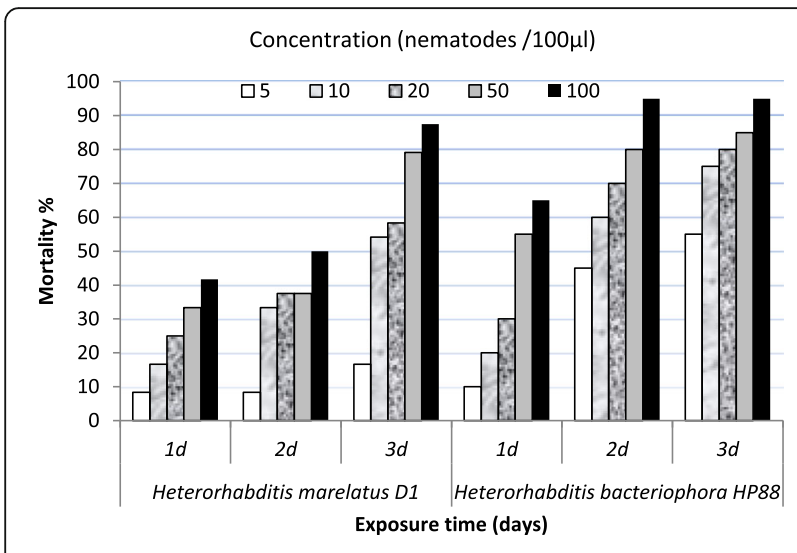

Fig. 4 Mortality percentages of Galleria mellonella after exposure to different concentrations of Heterorhabditis marelatus D1 and Heterorhabditis bacteriophora for different periods

Grewal et al. 2011). Somasekhar et al. (2002) in their bioassays on $S$. carpocapsae reported major differences in heat tolerance exist between isolates of same species.

\section{Suitability for controlling the peach fruit fly, B. zonata} Applying $H$. marelatus D1 in comparison to $H$. bacteriophora, at the two rates (5 and $15 \mathrm{IJs} / \mathrm{cm}^{2}$ of soil surface) on sandy soil containing old pupae (7 days old) of $B$. zonata, resulted in different mortality percentages of emerged B. zonata adults, according to the rate of nematode application rather than the nematode species (Fig. 5). At the rate $5 \mathrm{IJS} / \mathrm{cm}^{2}$ of soil surface $\left(5 \times 10^{8} \mathrm{IJs} /\right.$ ha), mortality percentages of $B$. zonata adults were 45 and $35 \%$ due to $H$. marelatus D1 and $H$. bacteriophora, respectively. At $15 \mathrm{IJs} / \mathrm{cm}^{2}$ of soil surface, the mortality of emerged adults was 77.5 and $75 \%$ due to $H$. marelatus D1 and $H$. bacteriophora, respectively.

The present study also indicated the suitability of this new isolate to the method of application that targets the newly emerged adults while still under the soil surface as it killed over $77 \%$ of them within $48 \mathrm{~h}$ after

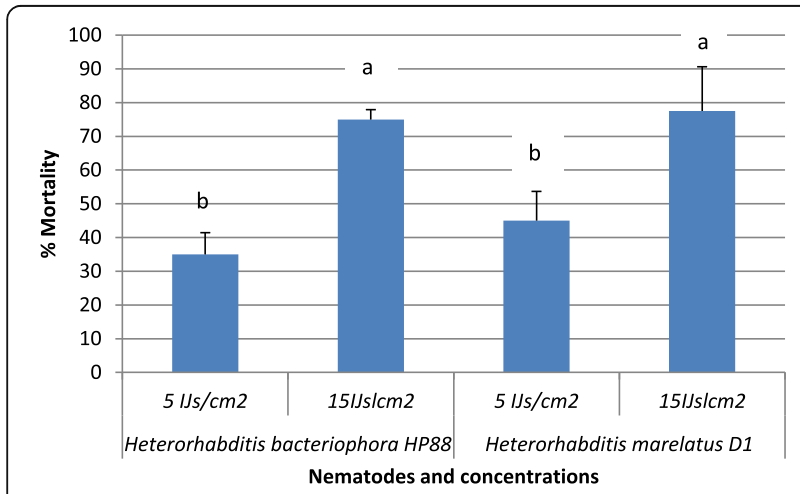

Fig. 5 Mortality percentages of Bactrocera zonata after applying different concentrations of Heterorhabditis marelatus D1 and Heterorhabditis bacteriophora emergence. The use of $H$. marelatus D1 may be a contribution to the biological control of B. zonata in Egypt and other countries of similar environmental conditions. In semi-field study, Mahmoud et al. (2016) reported that entomopathogenic nematodes could infect all stages of B. zonata. They stated that the adult stage was more susceptible to Steinernema feltiae infection than either the larvae or the pupae.

\section{Conclusion}

The Peach fruit fly Bactrocera zonata is a dangerous insect pest of many fruit crops. It is difficult to be controlled by the tradition chemicals due to the confining behavior of their larvae inside the fruits or their pupae in the soil. Entomopathogenic nematodes have been used in biological control since several decades. Unfortunately, it is not commercially used in the biological control of fruit flies worldwide because the available strains may be less tolerant against severe environmental conditions such as high temperature, drought and/or lack of oxygen. Also the application methods of EPNs against fruit flies might need optimization. The present study has documented the first record of Heterorhabditis marelatus D1 from Egypt. The new isolate was superior than the most commercialized species Heterorhabditis bacteriophora HP88 in heat tolerance (more than 5 times higher) desiccation tolerance (over 4 times higher) and hypoxic tolerance (about two times higher). It was comparable to the reference nematode in terms of its virulence to larvae of Galleria mellonella. The new isolate was suitable for the method of application that targeting the emerging adults of $B$. zonata under the soil surface as it killed over $77 \%$ of the emerged adults within $48 \mathrm{~h}$ after adult emergence.

\section{Authors' contributions}

MME Saleh and YA Mahmoud suggested the idea and designed the research. Hala MS Metwally conducted the molecular identification and the environmental tolerance assays. Saleh and Mahmoud conducted the efficacy assay against the Peach fruit fly. Saleh analyzed the data and wrote the manuscript. All authors contributed to the writing and approved the manuscript.

\section{Competing interests}

The authors declare that they have no competing interests.

\section{Publisher's Note}

Springer Nature remains neutral with regard to jurisdictional claims in published maps and institutional affiliations.

Received: 28 October 2017 Accepted: 12 January 2018 Published online: 08 March 2018

\footnotetext{
References

Anbesse S, Sumaya NH, Dorfler AV, Strauch O, Ehlers R (2013) Stabilization of heat tolerance traits in Heterorhabditis bacteriophora through selective breeding and creation of inbred lines in liquid culture. BioControl 58:85-93

El-Saadawy HA, Saleh MME (1999) Infectivity of Egyptian and imported entomopathogenic nematodes under different temperatures. J Ent Nematol 9(1):72-75
} 
Gaugler R (1988) Ecological considerations in the biological control of soilinhabiting insects with entomopathogenic nematodes. Agric Ecosyst Environ 24:351-360

Gaugler R (1997) Ecology in the service of biological control: the case of entomopathogenic nematodes. Oecologia 109:483-489

Gaugler R (2002) Entomopathogenic nematology. CABI Publishing, Wallingford

Glazer I, Salame L (2000) Osmotic survival of the entomopathogenic nematode Steinernema carpocapsae. Biol Control 18:251-258

Grewal PS, Bai XD, Jagdale GB (2011) Longevity and stress tolerance of entomopathogenic nematodes. In: Perry RN, Wharton DA (eds) Molecular and physiological basis of nematode survival. CABI Publishing, Wallingford, pp 157-176

Grewal PS, Bornstein-Forst S, Burnell AM, Glazer I, Jagdale GB (2006) Physiological, genetic and molecular mechanisms of chemoreception, thermobiosis and anhydrobiosis in entomopathogenic nematodes. Biol Control 38:54-65

Kapoor VC (1993) Indian fruit flies: (Insecta: Diptera: Tephritidae). Oxford \& IBH Publishing Co. Pvt. Ltd. India, New Delhi, p 228

Kaya HK (1990) Soil ecology. In: Gaugler R, Kaya HK (eds) Entomopathogenic nematodes in biological control. CRC Press, Boca Raton, pp 93-115

Kaya HK, Koppenhofer AM (1996) Effects of microbial and other antagonistic organism and competition on entomopathogenic nematodes. Biocontrol Sci Tech 6:333-345

Koppenhofer AM (2000) Nematodes. In: Lacey LA, Kaya HK (eds) Field manual of techniques in invertebrate pathology. Kluwer, Academic Press, Dordrecht, pp 283-301

Laznik Ž, Tóth T, Lakatos T, Vidrih M, Trdan S (2010) Oulema melanopus (L.) (Coleoptera: Chrysomelidae) adults are susceptible to entomopathogenic nematodes (Rhabditida) attack: results from a laboratory study. J Plant Dis Prot 117(1):30-32

Mahmoud YA, Ebadah IMA, Metwally HMS, Saleh MME (2016) Controlling larvae pupae and adults of the peach fruit fly, Bactrocera zonata (Saund.) with the entomopathogenic nematode, Steinernema feltiae. Egypt J Biol Pest Control 26(3):615-617

Marin M, Garcia-Lechuz JM, Alonso P, Villanueva M, Alcala L, Gimeno M, Cercenado E, Sanchez-Somolino SM, Radice C, Bouza E (2011) Role of universal 165 rRNA gene PCR and sequencing in diagnosis of prosthetic joint infection. J Clin Microbiol 50(3):583-589

Molyneux AS (1986) Heterorhabditis spp. and Steinernema spp.: temperature and aspects of behavior and infectivity. Exp Parasitol 62:169-180

Perry RN, Ehlers RU, Glazer I (2012) A realistic appraisal of methods to enhance desiccation tolerance of entomopathogenic nematodes. Nematol 44(2):185-190

Shamseldean MM (1994) Effects of temperature on survival and infectivity of Egyptian heterorhabditids nematode isolates. Egyptian. J Appl Sci 9(9):53-59

Shamseldean MM, Abou El-Sooud AB, Abd Elgawad MM, Saleh MME (1996) Identification of a new heterorhabditid species from Egypt, Heterorhabditis taysearae n. sp. (Rhabditida: Heterorhabditidae). Egypt. J. Biol. Pest Control 6(2):15-24

Shamseldean MM, Abou El-Sooud AB, Saleh MME (1996) Isolation of Steinernema carpocapsae (Waiser, 1955) Poinar, 1990. (Steinernematidae) Heterorhabditis bacteriophora Poinar 1976 and Heterorhabditis indicus Poinar et al., 1992 (Heterorhabditidae) as first record from Egypt. Egypt J Biol Pest Control 6(2):187-201

Shapiro-llan DI, Stuart RJ, Mccoy CW (2003) Comparison of beneficial traits among strains of the entomopathogenic nematode, Steinernema carpocapsae, for control of Curculio caryae (Coleoptera: Curculionidae). Biol Control 28:129-136

Shehata NF, Younes MWF, Mahmoud YA (2006) Anatomical effects of gamma-ray on the peach fruit fly, Bactrocera zonata (Saund.) male gonads. J App Sci Res 2:510-513

Shulong C, Ma J, Moens M, De Clercq P, Li X, Han R (2013) Characterization in biological traits of entomopathogenic nematodes isolated from North China. J Invert Pathol 114:268-276

Smits P (1996) Post-application persistence of entomopathogenic nematodes. Biocontrol Sci Tech 6:379-387

Somasekhar N, Grewal PS, Klein MG (2002) Genetic variability in stress tolerance and fitness among natural populations of Steinernema carpocapsae. Bio Control 23:03-310

\section{Submit your manuscript to a SpringerOpen ${ }^{\circ}$ journal and benefit from:}

- Convenient online submission

- Rigorous peer review

- Open access: articles freely available online

- High visibility within the field

- Retaining the copyright to your article

Submit your next manuscript at $\boldsymbol{\nabla}$ springeropen.com 